\title{
Language Teaching for Specific Purposes: A Case Study of the Degree of Accuracy in Describing the Character of Mental Disabilities in Modern Arabic Drama (Egyptian Film Toot-Toot as an Example)
}

\author{
Zain Saleh Alkayed \\ Department of Educational Sciences, Ajloun College, Al Balqa Applied University, Jordan \\ Amal Riyadh Kitishat \\ Department of English Language and Literature, Ajloun College, Al Balqa Applied University, Jordan
}

\begin{abstract}
The study aims at investigating the degree of accuracy in describing the character of mental disabilities in modern Arabic drama. The study takes the Egyptian Film Toot-Toot as an example. Toot -Toot is a film about a mentally handicapped heroine, "Kareema", who was sexually abused by a wealthy man, and she was also socially harassed by the people of her community. The study tries to prove that there is an accurate stereotypical representation of the mentally up-normal characters in Arabic n drama and cinema. To achieve the objectives of the study, the descriptive analytical approach was adopted. The sincerity and consistency of the study tool were confirmed the study summarized the film into eight scenes, then they were analyzed and discussed in light of the degree of accuracy of the general characteristics of mental disabilities which include the following: cognitive, physical, linguistic, the social and psychological characteristics. Also, the role of social institutions towards the mentally disabled is discussed. The results revealed that the purpose is to make the audience to be sympathized rather than empathized by the dramatic representation of the disabled character for the sake of increasing the cash revenue of the film. To sum up, the mentallyhandicapped characters were misrepresented; they were so far from the scientific and medical diagnosis.
\end{abstract}

Index Terms-Arabic television drama and cinema, Egyptian cinema, the representation of disabilities in Arabic cinema and drama, the stereotype of mentally handicapped people in cinema, Toot-Toot

\section{INTRODUCTION}

Toot-toot is an Egyptian that was produced in the nineties of the twentieth century. This film is about a mentally handicapped woman "Kareema" who was sexually abused by a wealthy man from her district, and she was also socially harassed by the people of her own community. The film was selected because it focuses on how the Egyptian drama represented the attitude of the modern Egyptian society towards the people of special needs in general and those who suffer from a mental illness in particular.

Media representation whether in Cinema or T.V drama is significant because it is an influential medium that can either create or shatter the way people think about disabled handicapped people. From this perspective, the study explores the degree of accuracy in describing the character of mental disabilities in modern Arabic drama. In this study, the researchers take the Egyptian Film Toot-Toot as an example.

It is worth noting that the idea of how people of the mental illness were characterized in the dramatic T.V. episodes or Cinematic production is a very sensitive issue. In other words, the presentation is varied; mostly it shows a negative presentation by hinting that these people are dangerous and harmful! However, even when they were fairly presented, they are misrepresented by having extreme exaggeration of the behavior. This reveals a contradiction to the medical diagnosis of these particular mental handicapped people.

\section{A. The Problem of the Study}

Most Arabic movies and dramatic productions tend to give a mistaken stereotype to the mentally handicapped characters. Therefore; many films present a sympathetic attitude toward the image of the people who suffer from handicapped problems, but the majority of the features that are presented in the films are in-accurate and highly exaggerated for film marketing aiming at urging the audience to sympathize rather than empathize. The features of the handicapped protagonists are far away from the true medical diagnosis. This kind of treatment is not real and distorts the truth by presenting a sequence of an intentionally false stereotypical image of the disabled in general and the 
mentally handicapped heroes in particular. Hence; this fact stimulates the researchers to explore the image of the handicapped characters in The Egyptian film Toot-Toot to trace the degree of the accuracy of such representations.

\section{B. The Questions of the Study}

The study attempts to answer the following questions:

1. What is the validity of the information provided about the characteristics of mental disability in the cognitive domain

2. How correct is the information provided about the characteristics of mental disability in the social field?

3. How correct is the information provided about the characteristics of mental disability in the motor field?

4. What is the validity of the information provided about the characteristics of mental disability in the emotional field?

5. Which is the validity of the information provided on mental disability in the linguistic field?

6. What is the role of social institutions in the field of mental disability?

\section{The Objectives of the Study}

The study aims at investigating the degree of accuracy in describing the character of mental disabilities in modern Arabic drama. The study takes the Egyptian Film Toot-Toot as an example. The study tries to prove that there is an accurate stereotypical representation of the mentally up-normal characters in Arabic drama. Some of the characteristics that are attributed to the mentally handicapped characters are true, but the majority of the features that are presented in the film are accurate and highly exaggerated for film marketing, to create a kind of influence to increase the turnout of the audience

\section{The Significance of the Study}

The choice of this film Toot -Toot came because the main character in the film is a girl who suffers from a mental disability. The film was shown for an hour and a half. The girl's character took over most of the film's scenes and was valuable material for the current study. Therefore, studying this film will enable us to check the degree of accuracy of the presentation of the disabled character in light of the medical and scientific diagnosis.

\section{REVIEW OF RELATED LITERATURE}

Many studies tackled the cinematic representation of the disabled characters in general and the mentally handicapped characters in particular. For instance, Romanska (2020) points out the hidden link between the handicapped character and the negative association of it. The stereotype of the evil cripple is "rooted in mythologies full of half-man half-beasts who possess pathological and sadistic desire" (Romanska, 2020).

Also, Molly Horan (2016) states that Cinema and T.V drama has a "history of being less than exemplary when it comes to ...characters with disabilities", some films have often "sentimentalized, frequently misinformed and at best-encouraged filmgoers to sympathies rather than empathized"(Horan, The Gurdian, 2016). Horan explored films and T.V shows that present characters with disabilities, he finds out that "Films tend to favor true stories that are dramatized. While they can tend to be maudlin or condescending, some of these films have proven to be sensitive portrayals of men and women struggling with disabilities"(Horan, 2016).

In addition, Winter et.al (2015), state that characters with disabilities are revealed to have cognitive incompetence and emotional conflict. The most important symptom is that their reaction to situations is slower than other normal characters. This could be seen in the character's reaction to verbal communication with others. The reaction applies to all types of words whether they have positive, neutral, or even negative associations (Winter et.al, 2015). Hence, Lin Meijun (2013) states that the source of drama is "the people's own experience", Lin Meijun discussed the important role that drama can play in forming a general impression on the viewers; he states that by embodying human action in the creative drama in both theory and practice, drama plays an important role in presenting human experience by focusing on tiny details of characterization of the major character. Lin Meijun highlights "spontaneity" as a major distinctive feature of the dramatic and cinematic production. In other words, drama plays an important function which is mainly an artistic function, still it "educates experience" (Meijun, 2013).

In "Disability in Film: Is Cinema finally moving with the Times?", David Cox argues that the importance of this type of film is not because they present disabled heroes and heroines, but it lies in the way the film treats these protagonists. He states this leads to a focus on the "untouchable centers on the parallels" between the caregiver and his disabled accusation". The major feature in such films is the "sense of exclusion" (Cox, 2012).

Taking such cinematic presentation of the disabled in mind, there is an indirect hint at the idea that disability was a "divine punishment, and that disabled people are a threat". Long more goes even further to claim that they were presented either as embittered, or by their fate, or even worse out of control, "eager to avenge themselves on the able-bodied"(Long more, 2003).

In "On screen and stage, disability continues to be depicted in outdated, clichéd ways", Misha Ketchell draws attention to the "increased sensitivity to gender and race representation in popular culture, disabled Americans are still awaiting their national (and international) movement" (Romanska, 2020). Furthermore, Romanska adds that the 
disabled characters are limited to four types: the "magical cripple," the "evil cripple," the "inspirational cripple" and the "redemptive cripple" (2020). Magical cripples exceed the boundaries of man's strength and are nearly supernatural they make miraculous things happen for able-bodied characters.

Shannon Kelly in her article "What do you think of how people with disabilities are portrayed in films and on TV?" discussed the negative representation of disability in films on TV. She says Hollywood portrayals of disabled people aren't great because most movies are about dramatized stereotypes, far away from reality (Kelly, 2018).

Abd al-Rahim referred to the mentally handicapped child who is characterized by some of the characteristics that are reflected in his mental abilities, namely withdrawal, hesitation, repetitive behavior, excessive movement, his inability to control his emotions, the inability to establish effective social relationships with others and tends to participate with the younger than him (Abd al-Rahim, 2012).

Shash (2002) states that individuals with severe disabilities suffer from good conditions, self-medication, difficulty in the soul, difficulty in the soul, and difficulty in love, how much they cannot help in protecting themselves, or their peers, throughout their whole life (Shakhs 2002).

As Al-Ajami indicated, people with disabilities are predominantly affected by emotional and social maladjustment that appears informing negative perceptions of themselves that lead to poor self-confidence and a low sense of security, in addition to feelings of helplessness and inferiority, severe dependence on others, and a sense of shyness, so the disabled individual tries to distance himself from others and introversion, which leads to some problems in the processes of social growth, and the acquisition of social skills necessary to achieve independence and a sense of self-sufficiency, and this may arise from limited movement and the inability to notice the behavior of others (Al-Ajami, 2020).

\section{METhOD AND PROCEDURES}

a. Methodology: The study uses the descriptive and analytical method for its relevance to the nature of the study, which adopts the interpretation of data logically and narratively.

b. Study population: The study population consisted of Arab dramas, films, and TV series that dealt with persons with disabilities.

c. Study sample: The study sample consisted of the movie Toot-Toot, an Egyptian film produced in 1993 by director Atef Salem.

\section{RESULTS}

To answer the first question, what is the validity of the information provided about the characteristics of mental disability in the cognitive domain? The eight scenes that contained the general characteristics of mental disabilities will be shown as follows:

Results of the analysis of the film "Toot - Toot" in the field of cognitive characteristics of mental disability

TABLE NO. (1)

Analysis Of The Scenes Of The Movie In Which The Focus Is On The Characteristics Of The Study

Scene Number (1)

\section{SCENE CONTENT}

The girl, Karima, mentally handicapped, ran in the market

wearing torn clothes, followed by several children throwing

stones at her and saying in one voice, Karima, the crazy woman,

and everyone looked at her and laughed and did not find help

from anyone, and she insulted the children with single words

(your mother, your father). And she tries to defend herself by

hitting the children who insult her

Scene Number (2)

\begin{tabular}{|l|l|}
\hline SCENE CONTENT : & NOTES \\
\hline $\begin{array}{l}\text { Karima entering hajj's shop (Helmy) Noticing people pounding through large } \\
\text { pistils asking for Hajj Helmy to work, charging it precisely through a } \\
\text { medium-sized paddle, while she is working, she hears the voice of the girls' hair } \\
\text { seller (Salama), and takes girls 'hair (sugar Sweet), and then the shopkeeper's } \\
\text { attempt to harass her, and then ask her to deliver the gas cylinders to the house } \\
\text { of al-Hajjah (and she is the one who cares for Karima }\end{array}$ & $\begin{array}{l}\text { Attention: } \\
\text { She pays attention to the voice of the candy seller } \\
\text { "Salama" and takes the sweets from him. }\end{array}$ \\
\hline
\end{tabular}

Scene Number (3)
The features of celebrating weddings appear as part of the popular rituals. When the child reaches the seventh day, the parents cleanse and make a celebration so that Karima participates in all the details of the celebration from its beginning to its end.

\section{SCENE CONTENT}

NOTES

1. A girl with low mental capabilities

2. According to the opinion of the law, at the end of the film, the girl suffers from a severe mental disability

NOTES
1. Attention:
Pay attention to the girl who is adorned, and ask for the same
Selective attention:
Watching the baby's rash and asking about it
3. Memory:
She wants the word "Shami and Rose", a phrase that I heard from the
shopkeeper (Helmy) to get sweets and return them to get sweets

Pay attention to the girl who is adorned, and ask for the same Selective attention:

She wants the word "Shami and Rose", a phrase that I heard from the shopkeeper (Helmy) to get sweets and return them to get sweets 


\begin{tabular}{|l|l|}
\hline 4. & $\begin{array}{l}\text { Awareness: } \\
\text { When she said to me that a kidney with your teeth approached you, she said } \\
\text { (them) a word for eating. }\end{array}$ \\
\hline
\end{tabular}

Scene Number (4)

\section{SCENE CONTENT}

In the celebration, Karima meets a wealthy man (his name is Mahrous). The scene moves to Karima washing her clothes, singing, Mahrous and Hajj Helmy look at her immorally. Then the scene moves to children throwing Karima with stones and trying to defend herself and beating Sambo and taking off her clothes while children assault her and the neighborhood people look at her and a guarded desire increased Out after seeing it like this

\section{NOTES}

1. Memory:

At the celebration, Karima raises her dress and says (Smell and his rose is Hajj), a phrase that the pilgrimage said to her in his shop a short time ago

2. Thinking:

When she heard the call to supplication, she arose and responded to the supplication

Scene Number (5)

\section{SCENE CONTENT:}

He leaves her unguarded and gets lost in the streets of the capital Cairo, she keeps walking until she reaches a place on the railway, she finds a place to go inside the railway

NOTES
1. Memory:
a. She sees Mahrous entering the hotel, you remember him and
follow him
b. She hears a Salama's beep, remembering him, and goes to him to
buy basbousa.
c. She wanders around the city and returns to its place on the railway
without getting lost.
2. Reflection:
She smartly evades hotel workers
3. Understanding:
She used the elevator correctly and appropriately
4. Attention:
a. She asks for an image, according to the opinion of the
shopkeeper, that represents the Virgin and Christ
b. She watches the sugarcane squeezing process imitating what you
saw
saw

Scene Number (6)

\begin{tabular}{|c|c|}
\hline SCENE CONTENT & NOTES \\
\hline \multirow{5}{*}{$\begin{array}{l}\text { Mahrous comes to the place where lives, which is a group of } \\
\text { iron on top of each other in the form of a very small room next } \\
\text { to the mosque, and he brings her the "basbousa" and lures it } \\
\text { into his car, and he takes it with him to his home, in his house } \\
\text { he orders the servants to take care of her from the physical side, } \\
\text { and after it is prepared he rapes her. }\end{array}$} & Understanding: \\
\hline & $\begin{array}{l}\text { 1. (Mahrous says, "Clean it" in the car. "Beeb says is an expression of } \\
\text { the car }\end{array}$ \\
\hline & $\begin{array}{l}\text { 2. When Mahrous tried to play the dog, she said, "No dog, where is the } \\
\text { tail." }\end{array}$ \\
\hline & $\begin{array}{l}\text { 3. Understanding and realizing (feeling sad and crying over what } \\
\text { happened with her }\end{array}$ \\
\hline & $\begin{array}{l}\text { 4. Understanding: responding to instructions when asked to wait for } \\
\text { him }\end{array}$ \\
\hline
\end{tabular}

Scene Number (7)

\section{SCENE CONTENT :}

The scene of decent birth, receiving help from the railway worker's wife, after childbirth she puts her son on her lap and the railway worker tries to help her expels him and leaves her with her newborn, she tries to perform the rituals that she witnessed when the children were born, she tries to feed what she eats and then, her feelings direct her to breastfeed

NOTES
1. Memory:
a. Performing the rituals that she witnessed when the birth of a child with her
son
b. She covered herself up when she breastfed her son in front of the security
official.
2. Understanding:
a. When she asks: Why is Fanoos?) Fanoos is the owner of the juice shop
when he asked her not to breastfeed her baby in front of people.
b. Sambo asked her where is this child? She said, Karima's son, her son, my
womb.
3. Perception:
the child's temperature rises, you realize that the child is sick
$\mathbf{4} \quad$ Realization:
When a bystander told her that the child should go to the hospital, she said
(death), meaning he could die
5. Attention:
When she follows up with the child while he is receiving treatment.

Scene Number (8)

\section{SCENE CONTENT}

Karima returns to the neighborhood bearing her son.

Meeting Mahroos, Karima strikes him, and the people of the neighborhood kick him out of the neighborhood.

NOTES

1. Understanding:
a. When she says a man in Military uniform Takes Sambo and gets Karima
home.
2. Memory:
Mahrous Bey, Jeb Basbousa, a car




\begin{tabular}{|l|l|}
\hline 3. Attention: \\
a. the perception you see the purification of children asking the argument to \\
purify her so \\
b. Mahrous, Jeb Basbousa, in a car, house, on a mattress \\
$\begin{array}{l}\text { 4. Understanding: } \\
\text { When she asks "what dish?" and when she describes what } \\
\text { guarded ...door lock, on a bed }\end{array}$ \\
\hline
\end{tabular}

To answer the first question: How correct is the information provided about the characteristics of mental disability in the cognitive domain? The results are as follows:

TABLE NO. (2)

\begin{tabular}{|c|c|c|c|c|}
\hline \multicolumn{5}{|c|}{ Mental characteristics } \\
\hline SCENES & Attention & Memory & Comprehension & Thinking \\
\hline $\begin{array}{l}\text { SCENE (1) } \\
\text { Karima the heroine of the movie is a low mental capacity girl. }\end{array}$ & & & & $\mathrm{X}$ \\
\hline $\begin{array}{l}\text { SCENE (2): } \\
\text { She pays attention: to the voice of the candy seller (Salama) and } \\
\text { takes the sweets from him }\end{array}$ & $\mathrm{x}$ & & & \\
\hline $\begin{array}{l}\text { SCENE (3) } \\
\text { She pays attention to the girl who adorns and asks to adorn herself }\end{array}$ & & & $\mathrm{x}$ & \\
\hline Watching the baby's circumcision and asking about this matter & & & & $\mathrm{x}$ \\
\hline Watching the boy's circumcision and asking about this matter & & & $\mathrm{x}$ & \\
\hline $\begin{array}{l}\text { SCENE (4) } \\
\text { the celebration scene, }\end{array}$ & & & $\mathrm{X}$ & \\
\hline $\begin{array}{l}\text { SCENE (5) } \\
\text { Mahrous says, "Kill it with his bus," the car says. "Beeb says," is } \\
\text { an expression of the sound of the car }\end{array}$ & & & $\mathrm{X}$ & \\
\hline $\begin{array}{l}\text { SCENE (6) } \\
\text { Asking about an image, according to the owner of the shop, that } \\
\text { represents the Virgin and Christ }\end{array}$ & & & & $\mathrm{X}$ \\
\hline Seeing the process of squeezing sugar cane imitate what you saw & & & $\mathrm{X}$ & \\
\hline Evading hotel workers cleverly & & $\mathrm{x}$ & $\mathrm{X}$ & $\mathrm{X}$ \\
\hline $\begin{array}{l}\text { SCENE (7) } \\
\text { Follow-up of the child while receiving treatment }\end{array}$ & $\mathrm{x}$ & & & \\
\hline $\begin{array}{l}\text { Doing the rituals that she witnessed when the birth of a child, with } \\
\text { her son and repeating the same phrases }\end{array}$ & & $\mathrm{X}$ & & \\
\hline $\begin{array}{l}\text { covering herself when she breastfeeds her son in front of the } \\
\text { security Responsible, and this request them (lantern) }\end{array}$ & $\mathrm{x}$ & & & \\
\hline $\begin{array}{l}\text { Scene(8) } \\
\text { she asks about the child's circumcision and expressed her wish to } \\
\text { get her circumcised }\end{array}$ & & & $\mathrm{x}$ & $\mathrm{X}$ \\
\hline $\begin{array}{l}\text { She was able to remember and identify Mr. Mahrous saying } \\
\text { "Mahrous Bay, give me Basbousa, car" }\end{array}$ & & $\mathrm{X}$ & & \\
\hline $\begin{array}{l}\text { Asking questions " what dish?" trying to explain what happened to } \\
\text { her "guarded door lock, on a bed" }\end{array}$ & $\mathrm{X}$ & & & \\
\hline
\end{tabular}

To answer the second question: How correct is the information provided about the characteristics of mental disability in the social field? The results are as follows:

TABLE NO. (3)

\begin{tabular}{|c|c|c|c|c|c|c|}
\hline \multicolumn{7}{|l|}{ Social Characteristics } \\
\hline SCENES & $\begin{array}{l}\text { Daily-living } \\
\text { skills }\end{array}$ & $\begin{array}{ll}\text { self-care } & \text { skills } \\
\text { General } & \\
\text { appearance } & \end{array}$ & $\begin{array}{l}\text { Self-independ } \\
\text { ence skills }\end{array}$ & $\begin{array}{l}\text { cash handling } \\
\text { skills }\end{array}$ & $\begin{array}{l}\text { general } \\
\text { safety skills }\end{array}$ & $\begin{array}{l}\text { adaptat } \\
\text { ion } \\
\text { skills }\end{array}$ \\
\hline $\begin{array}{l}\text { SCENE (1) } \\
\text { Untidy, dirty, torn clothes } \\
\text { The relationship with others: the mockery } \\
\text { and laughter of everyone at the disabled girl }\end{array}$ & $\mathrm{x}$ & & & & & \\
\hline $\begin{array}{l}\text { SCENE (2) } \\
\text { Eating skill: eat sweets with her hand }\end{array}$ & $\mathrm{x}$ & & & & & \\
\hline $\begin{array}{l}\text { SCENE (3) } \\
\text { She carries and distributes a basket of } \\
\text { sandwiches } \\
\text { Eating: She eats food normally by hand and } \\
\text { alone }\end{array}$ & & & $\mathrm{x}$ & & & \\
\hline $\begin{array}{l}\text { to attack or slap anyone who tried to harass } \\
\text { her }\end{array}$ & & & & & $\mathrm{x}$ & \\
\hline
\end{tabular}




\begin{tabular}{|l|l|l|l|l|}
\hline $\begin{array}{l}\text { The old woman demanding her to strike } \\
\text { everyone who approaches her badly }\end{array}$ & & & & \\
\hline $\begin{array}{l}\text { SCENE (4) } \\
\text { Karima washes her clothes and puts them in } \\
\text { a place to dry on her own without assistance }\end{array}$ & $\mathrm{x}$ & & & \\
\hline $\begin{array}{l}\text { She verbally assaulted anyone who } \\
\text { assaulted her. }\end{array}$ & & & & \\
\hline SCENE (5) Eating skill: & $\mathrm{x}$ & & & \\
\hline $\begin{array}{l}\text { SCENE (6) } \\
\text { Street Crossing Skills: She alone crosses the } \\
\text { busy street, helping a child cross the street }\end{array}$ & $\mathrm{X}$ & & & \\
\hline $\begin{array}{l}\text { SCENE (7) } \\
\text { feeding herself and taking care of the baby }\end{array}$ & & & $\mathrm{X}$ & \\
\hline $\begin{array}{l}\text { SCENE (8) } \\
\text { Take responsibility: fear for the child from } \\
\text { strangers }\end{array}$ & & & & \\
\hline
\end{tabular}

To answer the third question: How correct is the information provided about the characteristics of mental disability in the motor field? The results are as follows:

TABLE NO. (4)

\begin{tabular}{|c|c|c|c|c|c|}
\hline \multicolumn{6}{|l|}{ Physical and kinetic properties } \\
\hline SCENES & $\begin{array}{l}\text { Physical } \\
\text { health }\end{array}$ & Visible deformities & $\begin{array}{l}\text { Movement } \\
\text { consistency }\end{array}$ & $\begin{array}{l}\text { Visual } \\
\text { kinesthetic } \\
\text { synergy }\end{array}$ & $\begin{array}{l}\text { great and minute } \\
\text { kinesthetic skills }\end{array}$ \\
\hline $\begin{array}{l}\text { SCENE (1) } \\
\text { Physical form: beautiful and adorable, there are } \\
\text { no distortions }\end{array}$ & & $\mathrm{x}$ & & & \\
\hline Health condition: very good & $\mathrm{x}$ & & & & \\
\hline $\begin{array}{l}\text { The presence of deformities: the right leg is } \\
\text { obstructed, the palm of the right leg is bent } \\
\text { inward }\end{array}$ & & $\mathrm{x}$ & & & \\
\hline $\begin{array}{l}\text { She hurls stones that are thrown at her with the } \\
\text { left leg }\end{array}$ & & & & & $\mathbf{X}$ \\
\hline $\begin{array}{l}\text { She raises her foot and takes off her shoes to hit } \\
\text { the children }\end{array}$ & & & $\mathrm{X}$ & & \\
\hline $\begin{array}{l}\text { SCENE (2) } \\
\text { The way to walk with the feet inside Hajj } \\
\text { Helmy's shop }\end{array}$ & & & & & $\mathbf{X}$ \\
\hline $\begin{array}{l}\text { She holds gas cylinders one on the head and one } \\
\text { rolling by the foot }\end{array}$ & & & & & $\mathbf{X}$ \\
\hline $\begin{array}{l}\text { She pounded some materials in a medium-sized } \\
\text { iron pestle }\end{array}$ & & & $\mathrm{x}$ & & \\
\hline She eats the sweets with her hand & & & & & $\mathrm{X}$ \\
\hline $\begin{array}{l}\text { SCENE (3) } \\
\text { She dances with the melodies of the music }\end{array}$ & & & $\mathrm{x}$ & & $\mathbf{X}$ \\
\hline $\begin{array}{l}\text { She carries a basket of sandwiches and } \\
\text { distributing them }\end{array}$ & & & $\mathrm{x}$ & & $\mathbf{X}$ \\
\hline $\begin{array}{l}\text { SCENE (4) } \\
\text { She eats alone and feeds the dog }\end{array}$ & & & & $\mathrm{X}$ & $\mathbf{X}$ \\
\hline $\begin{array}{l}\text { SCENE (5) } \\
\text { Good eating skill }\end{array}$ & & & $\mathrm{X}$ & & \\
\hline $\begin{array}{l}\text { When entering the bathroom, she walked } \\
\text { straight, and the shape of the foot was not a } \\
\text { proper curve }\end{array}$ & & & $\mathrm{X}$ & & $\mathbf{X}$ \\
\hline $\begin{array}{l}\text { She sat cross-legged by the bathroom sink, } \\
\text { without falling and balanced }\end{array}$ & & & & & $\mathbf{X}$ \\
\hline $\begin{array}{l}\text { Mahrous's resistance when he tried to rape her, } \\
\text { and verbal and physical aggression against him }\end{array}$ & & & & & $\mathbf{X}$ \\
\hline $\begin{array}{l}\text { SCENE (6) } \\
\text { Street crossing skills and helping a child to cross } \\
\text { the street }\end{array}$ & & & & & $\mathbf{X}$ \\
\hline Pick up the ax and try to work & & & & & $\mathbf{X}$ \\
\hline she runs over a narrow area in a straight line & & & $\mathrm{X}$ & & $\mathbf{X}$ \\
\hline $\begin{array}{l}\text { SCENE (7) } \\
\text { She Cooperated with the lady who helped her in } \\
\text { the birth process }\end{array}$ & & & & & $\mathbf{X}$ \\
\hline She Properly carries and breastfeeds the child & & & $\mathrm{X}$ & & \\
\hline $\begin{array}{l}\text { SCENE ( } 8 \\
\text { he hit Mahrous on the head directly, wounding } \\
\text { him after taking the candy stick from Salama }\end{array}$ & & & & & $\mathbf{X}$ \\
\hline
\end{tabular}


To answer the fourth question, which is the validity of the information provided about the characteristics of mental disability in the emotional field? The results are as follows

TABLE NO. (5)

\begin{tabular}{|l|l|l|l|l|l|}
\hline Scene & Aggression & $\begin{array}{l}\text { excessive } \\
\text { movement }\end{array}$ & $\begin{array}{l}\text { stereotyped } \\
\text { behavior }\end{array}$ & routine behavior & empathy \\
\hline $\begin{array}{l}\text { Scene(1) } \\
\text { hitting children and insulting } \\
\text { them "your father, your mother" }\end{array}$ & $\mathrm{X}$ & & $\mathrm{X}$ & & \\
\hline $\begin{array}{l}\text { Scene(2) } \\
\text { The transformation from sadness and } \\
\text { crying to a state of happiness when } \\
\text { she worked in the Hajj shop }\end{array}$ & & & & & \\
\hline $\begin{array}{l}\text { She hit several people when } \\
\text { distributing sandwiches }\end{array}$ & $\mathrm{X}$ & $\mathrm{X}$ & & & \\
\hline $\begin{array}{l}\text { when the child tried to dance with her, } \\
\text { she pushed the child back }\end{array}$ & $\mathrm{X}$ & & & & \\
\hline $\begin{array}{l}\text { Scene(4) } \\
\text { she responds to the spiritual call with } \\
\text { supplication by taking a candle, } \\
\text { lighting it, and making supplication }\end{array}$ & & $\mathrm{X}$ & & & \\
\hline $\begin{array}{l}\text { Scene(5) } \\
\text { Feeling sad and crying because of } \\
\text { what happened with her }\end{array}$ & & & & & \\
\hline $\begin{array}{l}\text { Scene(6) } \\
\text { The feeling of being pregnant }\end{array}$ & & & & & \\
\hline $\begin{array}{l}\text { Scene(7) } \\
\text { Fear of the child from the railroad } \\
\text { worker and trying to expel him } \\
\text { Breastfeed the child from her without } \\
\text { any previous knowledge }\end{array}$ & & & & & \\
\hline $\begin{array}{l}\text { Scene(8) } \\
\text { Feelings of anxiety and intense fear } \\
\text { for the child in the hospital } \\
\text { Aggression hit Mahrous after } \\
\text { remembering what happened to her }\end{array}$ & & & & & \\
\hline
\end{tabular}

To answer the fifth question, which is the validity of the information provided on mental disability in the linguistic field? The results are as follows:

\begin{tabular}{|c|c|c|}
\hline \multicolumn{3}{|l|}{ TABLE (6) } \\
\hline Scene & $\begin{array}{l}\text { receptive } \\
\text { language }\end{array}$ & $\begin{array}{l}\text { expressive } \\
\text { language }\end{array}$ \\
\hline $\begin{array}{l}\text { Scene } 1 \\
\text { insulting them "your father, your mother" }\end{array}$ & & $\mathrm{X}$ \\
\hline $\begin{array}{l}\text { Scene } 2 \\
\text { The use of one word for the expression "Hajjah tube, ring Hajj, Ace Haj, Bush, } \\
\text { safety." }\end{array}$ & & $\mathrm{X}$ \\
\hline $\begin{array}{l}\text { Scene } 3 \\
\text { She used the word "beggars" to describe those who to take the sandwiches from her. }\end{array}$ & & $\mathrm{X}$ \\
\hline She used the word "Walk you little girl", to the little girl who did the dance & & $\mathrm{X}$ \\
\hline $\begin{array}{l}\text { She used the word "Sweet Hajjah" to describe the good woman and ask her to put } \\
\text { Kohl "eyeliner" for her }\end{array}$ & $\mathrm{X}$ & \\
\hline She used the word "In the name of Allah, Masha Allah" to express gratitude & & $\mathrm{X}$ \\
\hline She used the word (what's that?) in the scenes of circumcision) & & $\mathrm{X}$ \\
\hline She used the word Smell a rose & $\mathrm{X}$ & \\
\hline $\begin{array}{l}\text { Scene (4) } \\
\text { She Prays to god with the sentence: } \\
\text { ( O Lord, let Kareema until morning to strike Sambo, and hit the soldier" }\end{array}$ & & $\mathrm{X}$ \\
\hline Karima says to Mahrous: "Basbousa, red, large" & $\mathrm{X}$ & \\
\hline $\begin{array}{l}\text { she verbally assaulted a man saying fragments, some phrases "your father, your } \\
\text { mother, says "O Lord, take you, O Lord, death" }\end{array}$ & & $\mathrm{X}$ \\
\hline $\begin{array}{l}\text { She said full sentences: } \\
\text { 1. "No, I will go home to Hajj" she } \\
\text { 2." Hajj, Helmy, is also sweet" }\end{array}$ & & $\mathrm{X}$ \\
\hline Some fragmentary sentences: "Sambo man, ski man, guarded man". & $\mathbf{X}$ & \\
\hline
\end{tabular}

And to answer the sixth question, which is what is the role of social institutions in the field of mental disability? The results are as follows: 
TABLE (7)

\begin{tabular}{|c|c|}
\hline \multicolumn{2}{|r|}{ The role of social institutions in the field of mental disability } \\
\hline $\begin{array}{l}\text { Religious institutions: The } \\
\text { Mosque\& Church }\end{array}$ & Neither the mosque nor the church show any role in protecting the disabled girl \\
\hline Law \& order Institution & $\begin{array}{l}\text { When Karima entered the police center for investigation the knowledge of, the man of charge in the security } \\
\text { center realized that she suffers from a mental disability and is carrying a child, he did not make any } \\
\text { recommendation for assistance, but only paid the bill for her as an expression of compassion and left her with } \\
\text { her child without communicating with any party to protect the girl and the child. There is no official role for } \\
\text { human rights centers to defend the rights of mentally disabled people. }\end{array}$ \\
\hline $\begin{array}{l}\text { Health care institutions: } \\
\text { hospitals and medical } \\
\text { centers }\end{array}$ & $\begin{array}{l}\text { When Karima entered the hospital to treat the child and with the doctor knowing that the girl suffers from a } \\
\text { mental disability and cannot take care of the child at all, he spoke with her as if she was a normal person and } \\
\text { did not communicate with any party to provide care for the child first and the mother secondly, although this is } \\
\text { the core of professional ethics of Medicine. }\end{array}$ \\
\hline Social institutions & $\begin{array}{l}\text { Care and rehabilitation centers: There is no reference in the film for the existence of any institution for the care } \\
\text { and rehabilitation of the mentally disabled }\end{array}$ \\
\hline
\end{tabular}

\section{DISCUSSION}

After reviewing the results of the study, the researchers found a set of general observations about the dramatic film, the focus of the research, and these observations are:

The film did not address the issue of diagnosing mental disability, it presented a completely different picture of society, especially since the film's heroine is a disabled girl who is present in the street and is open to abuse by everyone, and this never exists in Arab society, as we may find the disabled male individual in the street, but we never find that for girls with disabilities due to the cultural and ethical dimension And the moral one who considers approaching the girl an honor crime punishable by society before the law.

The results will be discussed according to the opinion of the law, which described Karima's condition as suffering from a severe mental disability.

Definition of severe mental disability according to IQ (they are individuals whose IQ score on IQ tests is from (25-40) .definition of severe mental disability according to the educational dimension (classified into dependents)

To answer the first question, which is: How correct is the information provided about the characteristics of mental disability in the cognitive domain? The results were as follows: Concerning the first cognitive characteristics and the foundation stone for all other cognitive abilities:

1. (Attention) Attention is the first cognitive process we practice when dealing with environmental sensory stimuli before perception (Muhanna, 2018). Also, in another situation in which Karima was in the neighborhood and the neighborhood was full of attitudes and views and all kinds of external stimuli, where the scene represented a state of holding weddings and events. Karima left all the signs of joy, joy, and adornment that are supposed to be the focus of her attention due to the colors and sound, as they are considered to attract attention and focus only on The ritual (purification) did not stop the matter at this point, but also asked what is this thing?

And in a later situation, after a year of witnessing her purification, she returns and focuses the same way and the idea on the purification of children. She showed high attention and focus in most situations, especially selective attention. Therefore, this attention requires great energy and effort from the individual because the distracting factors are often high and the motivation for continuing attention may not be high, and this matter is completely inconsistent and does not apply definitively to the characteristics of severe mental disability in the area of attention (Abdullah, 2010). Al-Azza ensures that the lack of attention of the mentally handicapped is due to their inability to use appropriate visual stimuli (Al-Azza, 2000).

As well as Ahmed and Badr indicated that poor attention and a high vulnerability to distraction are among the characteristics of the mentally handicapped (Ahmed and Badr, 2005). However, the film dealt with this characteristic opposite to the characteristics of the mentally disabled in the field of attention.

2. (Memory): a cognitive process concerned with storing what has been acquired from information, to retrieve it when needed after a period that may be lengthened or shortened (Jaber, 2021). In the scenes of the film, the remarks in the field of memory were as follows: In the situation in which Hajj, Helmy, tried to harass a cream, he asked her to lift her dress using the word "Smell a Rose" and after some time, during the celebration, Also, memory is weak and remembering slow it is accompanied by difficulties in retrieving information and memories are usually inaccurate (Adel, 2014).

Likewise, mentally handicapped individuals are characterized by their weak ability to retain information, the difficulty of recalling information when needed, and memory problems increase with the increase in the severity of the disability, and it becomes its lowest in cases of severe mental disability (Jaber, 2021). Deficiency in the field of memory is a natural thing because attention is the first cognitive process, then memory (Al-Failakawi, 2007). If the individual, suffers from a lack of attention, he will, accordingly, suffer from memory deficiencies

3. (Recognition): a mental, psychological process that helps any person to know his external world and reach the meanings and connotations of things, by organizing sensory stimuli, to interpret and formulate them into meaningful faculties. In the film, a group of scenes was observed in which Karima's cognitive ability was 
evident, for instance; when he asked not to breastfeed her son in front of people, and in the situation where the child's temperature rises, she realizes that the child is sick when it rose His temperature, and when a bystander told her to take the child to the hospital, she said (death). This is what he indicated (Al Shakhes, 2008) who said that the difficulty of perception varies according to the degree of mental disability, as it is difficult for people with severe mental disabilities to distinguish between shapes, colors, sizes, weights, smell, and taste. And the ability to perceive is affected by the level of the functioning of the senses (Al Shakhes, 2008).

4. (Thinking): It is the process by which information and experiences that the individual had previously learned and reorganized to face the new situations (i.e. the ability to solve problems) appeared in the film a group of scenes that showed a certain level of thinking in Karima, among which, when she heard the call to prayer, she rose and responded She called for simple words and sentences, and even took candles with her, meaning she was able to make a decision and take a procedure indicative of good thinking abilities. Through these scenes, it was found that Karima possesses thinking abilities that ranged from high, as in the hotel, to medium and normal, and this matter does not apply definitively to the thinking characteristic of people with severe disabilities which include:

1. Deficiencies in the attention process

2. Deficiencies in memory

3. Failure to form disparate mental images

4. Weakness in the syntax

And to answer the second question, which is to what extent the information provided about the characteristics of mental disability in the social field is correct? The movie scenes are analyzed and discussed as follows:

Mercer introduced the definition of social skills or adaptive behavior as that social role expected of the individual compared to his counterparts from the same age group to which he belongs, and this concept includes the social roles expected of the individual, especially his ability to social responsibility and the social skills expected of him (Khatib, Hadidi, 2009).

The adaptive behavior test has been adopted as a basic criterion in the diagnosis of mental disability. The basis for mental disability is a disorder in two or more aspects of adaptive behavior, and the more severe the mental disability, the lower the adaptive behavior skills.

At the beginning of the film, Karima appeared untidy and unclean, and torn clothes and everyone was mocking her and laughing at her and she could not defend herself at all, but in the scene in which the Hajj bought her sweets, she ate sweets with her hand without any help, and in another scene she eats at the dining table in a very organized manner in a guarded house and another scene she buys food from the seller alone and eats it Without any anomalous appearance of eating, the film presented two opposing positions at the same time the position of total impotence and the position of the other, mastering the skill of eating.

To answer the third question: How correct is the information provided about the characteristics of mental disability in the motor field? After analyzing the scenes, they are discussed as follows:

Karima's physical shape: Karima appeared beautifully and lusciously. There are no abnormalities in the organs responsible for movement and she did not suffer from any health problem at all. At the beginning of the film, the film showed that Karima's right foot was bent inward so that the way of walking was inconsistent due to that curve. But when I entered the Hajj shop, my dream walked normally, and when I carried gas cylinders on her head and rolled one with her foot, and this matter requires strength, physical, balance, and coordination of a psychomotor and skeletal system. Likewise, in two scenes from the film, Karima was dancing to music with the rhythm of the music, and her auditory-kinesthetic perception was very high.

Karima showed in many scenes great coordination of movement. However, she did not suffer from any imbalance in the process. When entering the bathroom, she walked straight and the shape of the foot was not a proper curve, and she squatted at the bathtub without falling and balanced. All this while she suffers from a curvature of the foot to the origin of this poses a problem for her in all these skills.

As Al-Maghazi (2004) indicated that the most important physical characteristics that distinguish mental disability are less weight and smaller than the ordinary, deficiencies in motor functions and nervous coordination, more susceptible to disease than others. He pointed out (Al-Qamish, 2007), the rate of physical and mental development of the mentally handicapped tends to decrease in general. The degree of decline increases with the increase in the severity of the disability. Especially in the head and face, and sometimes in the upper and lower extremities.

And to answer the fourth question, which is to what extent the information provided about the characteristics of mental disability in the emotional field is correct? The results are discussed as follows:

Kirk and Al-Sartawi et al defined the behavioral problem as is a deviation from age-appropriate behavior that affects the individual's growth and development and affects the lives of others (Kirk; Gallagher \& Anastasiow, 2003). Social and emotional adjustment is highly correlated with mental ability (Al-Sartawi et al., 2012), and those with mental disabilities show a clear decline in social adjustment and a lack of tendencies.

Al-Khatib (2003) indicated that the mentally handicapped are among the most people who suffer from behavioral problems due to their inability to define socially acceptable aspects of behavior. Also Al-Rousan (2001) indicated a set of common behavioral characteristics of mentally handicapped individuals that make them more susceptible to 
behavioral problems compared to others. Among the most important of these characteristics: the apparent lack of ability to learn, problems of poor attention and concentration, frustration and a sense of failure, the problem of remembering, and the apparent lack of transmission of the impact of learning.

To answer the fifth question, which is the validity of the information provided on mental disability in the linguistic field? The film displayed the following linguistic characteristics:

Communication is the process that is circulated in the exchange of ideas and information and the expression of needs and desires among the participants in the communication process, and it is the purpose and function of the language. Al-Amayrah, Al-Natour (2012), Al-Rousan (2000), and Kitishat and Al Omar Al Omar (2021) defined it as a method of social communication, a method of mental and emotional development. They look different from each other.

The linguistic use of Karima in the scenes of the film was as follows: Karima used a group of single words and the use of the single word was correct, such as cursing with one word, (your father, your mother) (tube, Salama, sheathing, sweet, cream, eye, Hamra, large) all of these The vocabulary was spelled correctly by Karima and they were single words

In other situations, sentences said, and these sentences are considered according to linguistic development within the telegraphic language level (i.e. the language that contains words without prepositions or nouns or a sign such as (Doki Aj, means more accurate oh Hajj) (Ace Hajj, meaning what Hajj) (Walk a bit, I mean, walk, girl. I mean, a red and large basboush),

Al-Rousan (2000) indicated that the most important manifestations of language disorders among the disabled are:

First: Speech disorders. It includes deletion, substitution, addition, distortion)

Second: Voice disturbances, which include: the pitch of the voice in terms of its intensity, loudness, low, or quality

Third: Speech disorders, including stuttering, standing up while speaking, and excessive speed of speech

Fourth: Language disorders, including a delay in the emergence of language, loss of the ability to understand and produce the language, difficulty writing, difficulty remembering, difficulty understanding a word or sentences.

Al-Batayneh and Al-Jarrah (2009) indicated linguistic development does not develop in isolation from cognitive abilities, it is natural that we find people with mental disabilities suffering from difficulties in the linguistic aspect, and in performing tasks dependent on the verbal and linguistic side.

And to answer the sixth question, which is: What is the role of social institutions in the field of mental disability?

What was noticed during the screening of the film was as follows:

First: The role of religious institutions (the mosque and the church): The film did not show any role for either of them, but rather it showed a decent living in a very simple place next to the mosque and supporting herself, and no one would help her or extend a helping hand to her.

No role appeared for the church because the film represents the Muslim community. This contradicts everything known about the role of religious institutions in providing protection and cares for the mentally handicapped since the beginning of dealing with mental disability, as the church was the first to provide care, including protection, shelter, clothing, and food for the mentally handicapped, in Islam, which provided all the rights for this group.

Second: The legal institutions (security centers, human rights centers): The film did not show any party responsible for defending the rights of persons with disabilities, as Egyptian society has shown that it is a society of chaos Kitishat and Al Kayed (2021). About the legal aspect, when Karima was arrested on charges of begging and presented to the legal official an order to release her. Finally, the protection, care, and follow-up of individuals with disabilities, even though they are the executive authority for the laws and legislations that provide for the protection and rights of people with disabilities.

Third: Health institutions (hospitals): When Karima's baby became ill and he was taken to the hospital and the doctor examined him, he spoke with Karima as a normal person and reassured her and asked her to take care of the child, with the doctor knowing that she suffers from a mental disability and is completely unable to care and care for the child and this What is confirmed by medicine in the field of medical diagnosis of mental disability, the film showed the role of hospitals as superficial, irrational and irrational in the field of mental disability.

Fourth: Social Institutions (Care and Rehabilitation Centers): The film did not deal with this dimension definitively, and it seems that the society in which Karima grew up was within a society in which there are no institutions that care for the special needs and handicapped people.

All of this passive presentation was presented in this movie that was watched by millions of people. This eludes to a clear failure on the part of the competent authorities regarding the rights of the mentally handicapped in particular, or those who have special needs.

\section{CONCLUSION}

Drama in this field stands at the forefront of that media, where life emerges - drama after it contained in its special form the objective laws that control its existence and progress. Hence the increasing importance of studying drama in a detailed, in-depth study that does not stop at the task of purely academic studies, but rather as a conscious, methodical answer that expresses the extent to which our contemporary world can be portrayed, and the criterion for this possibility is the extent to which this drama embodies the values and cultural phenomena that people create through their 
experiences and the strength of their work. Having in mind the important role of drama and cinema in communication, the researchers highlight the significant role cinema could play in correcting the attitudes of the people to the character of the mentally- handicapped person, by directing an accurate image about this category of handicapped people who were misrepresented in both drama and cinema.

The visual drama has real power in conveying images from people and societies and informing the minds due to its widespread and its ability to dazzle and take over the times of viewers. It also builds images accumulated in their minds, which makes them link between these images presented in the drama and the reality around them, as well as the reality of people. The ideas presented and their repetitions almost continuously, enable them to create a stereotype and formulate it among the masses, the mental images and social reality presented by the means of communication regarding the issue of people with disabilities, make the public believe that this is the actual reality of PWD. If television portrays them in a negative and distorted way in some movies and series, then when television viewers meet an individual with a disability in front of them, they will bring up the negative images they saw, and they will deal with the disabled on this basis. Thus, it confirms the importance of transmitting real images of persons with disabilities because this will contribute to enhance positive mental images among the mass media, especially television and drama.

\section{REFERENCES}

[1] Abdel Rahim, S. (2011). The effectiveness of a behavioral program in developing some behavioral skills for mentally handicapped children who can teach, Damascus University Journal - Volume 27, pp.89-196.

[2] Ahmad, A, Badr, and Fai'ia. (2005). Attention deficit and hyperactivity disorder in children, its causes, diagnosis, and treatment. Riyadh: Publications of the Arab Academy for Special Education.

[3] Al Shakhes, A.et.al. (2017). The scale of academic skills among children with mild mental disabilities, Egypt: Psychological Counseling Journal, Issue 49, pp. 658-658.

[4] Al-Ajmi, N. (2020). Common mental disorders Islamic Education. Education Group. Group of numerical educational sciences (11) Kingdom of Saudi Arabia: Imam Muhammad bin Saud Islamic University press.

[5] Al-Ezzah, S. (2000). Special Education for People with Mental, Visual, Hearing and Kinetic Disabilities. Amman: House of Culture for Publication and Distribution.

[6] Al-Failakawi, M. (2007). The differences in the dimensions of family interaction within the families of students with $\begin{array}{lllll}\text { disabilities. } & \text { scumj.journals., } & \text { Retrieved } & \text { June } & \text { 2021from }\end{array}$ https://scumj.journals.ekb.eg/article_158957_58b882ac816400f2cbbf691813735b5e.pdf

[7] Alhomoud. G. and Sayed M. (2020). The Articulation of Language of Anger in the Arabic Language: A Contrastive Cultural Linguistic Approach. The Asian EFL Journal. Volume 27 Issue 5.1, pp.71-91.

[8] Al-Khatib, J. (2003). Modifying the behavior of children with disabilities, a guide for parents and teachers, Al-Falah Library, Al-Ain.

[9] Al-Khatib, J., Al-Hadidi, M. (2009). Introduction to Special Education. Amman: Dar Al-Fikr.

[10] Al-Qamish N., Al-Ma`aytah, K. (2007). The psychology of children with special needs, an introduction to special education. Dar Al-Masirah for printing and publishing: Amman.

[11] Al-Rousan, F. (2001). The Psychology of Extraordinary Children, Introduction to Special Education. Fifth Edition. Dar Al-Fikr for Printing, Publishing, and Distribution, Amman.

[12] Al-Sartawi, A. et.al. (2012). The Effectiveness of a Behavioral Program to Alleviate the Severity of Behavioral Problems for a Group of People with Mental Disabilities who can Learn, University of Sharjah. Journal of Human and Social Sciences. Volume (9), Issue (3), pp. 119-134.

[13] Cox, D. (2012). Disability in Cinema finally moving with the times. The guardian.12. Nov. 2012.Retrieved March 11, 2021 from https://www.theguardian.com/film/filmblog/2012/nov/12/disability-in-film-untouchable

[14] Horan, M. (2016). Ten Movies \&T.V shows that increased Disability Visibility. Retrieved May 20,2021 from https://www.refinery29.com/en-us/2016/06/111832/movies-about-physical-disabilities-handicap

[15] Jaber, A.(2021). A Teacher's Guide to Program Planning and Teaching Methods for the Mentally Handicapped. Retrieved April 2, 2021 from $\mathrm{http}: / / \mathrm{dr}$-banderalotaibi.com

[16] Kelly, S. The Conversation. (ed.) Misha Ketchell. Retrieved June2, 2021 from https://disabilityhorizons.com/author/DH-Shannon-kelly.

[17] Kitishat, A. R. , Al Omar, K. H.; Al Momani, M. A. K. (2020). The Covid-19 Crisis and Distance Learning: E-Teaching of Language between Reality and Challenges. Asian ESP Journal; 16(51):316-326. Article | Scopus | ID: covid who-958777. Retrieved March 11, 2021 from https://www.elejournals.com/asian-esp-journal/volume-16-issue-5-1-october-2020/

[18] Kitishat, A., Al Kayed, M. (2020). Political Repression in Arabic Theatre: A Case Study of Egyptian Theatre .Asian English for $\begin{array}{llllll}\text { Specific } \quad \text { Purposes. } & \text { Retrieved } & \text { J } 1.2) .82-93 . & 2021 \mathrm{from}\end{array}$ https://www.asian-esp-journal.com/volume-16-issue-1-2-february-2020/

[19] Kitishat, A.R. (2012). Colonialism and the Recreation of Identity: The Irish Theatre as a Case Study. Journal of Language and Culture. Vol. 3(5). pp. 83-86.

[20] Kwon, A. (2019). Inclusivity in Adult Education: A Reflection on Dis-Ability. European Commission. Retrieved March 6, 2021 from https://epale.ec.europa.eu/en/blog/inclusivity-adult-education-reflection-dis-ability

[21] Paul Longmore. (2003). Why I Burned My Book and Other Essays on Disability. Philadelphia, PA: Temple University Press.

[22] Maghazi, I. (2004). An Introduction to Mental Retardation, Egypt: The Academic Library.

[23] Muhanna, A. (2018). Cognitive Psychology. Egypt: Justice Press for Publication and Distribution

[24] Romanska, M. (2020). The Conversation. (ed.) Misha Ketchell, Retrieved June 26, 2021 fromhttps://theconversation.com/on-screen-and-on-stage-disability-continues-to-be-depicted-in-outdated-cliched-ways-130577 
[25] The Chicago Lighthouse. (2021). Media and People with Disabilities: Are We Represented Accurately? Retrieved April 12, 2021 from https://chicagolighthouse.org/sandys-view/media-and-people-with-disabilities/

Zain Saleh Alkayed: an assistant professor in Department of Educational Sciences at Al Balqa Applied Univertsity, Ajloun College. She is specialized in special education and published many articles in this field.

Amal Riyadh Kitishat: an associate professor in English literature. Formerly she held the position of the head of department of basic sciences and English language and literature. She is known for her scholarly interests in the field of theatre and applied dramatic educational studies. 